\title{
Analisis kesulitan siswa SMP dalam memahami konsep kubus balok dan alternatif pemecahannya
}

\begin{abstract}
Mutia $^{1}$
Abstrak: Penelitian ini bertujuan untuk mendiagnosis kesulitan belajar siswa SMP dalam mehamai materi kubus balok dan menemukan alternatif pemecahannya. Jenis penelitian ini adalah penelitian deskriptif dengan pendekatan kualitatif. Instrumen yang digunakan adalah tes geometri dan wawancara. Hasil penelitian ini menunjukkan bahwa siswa mengalami kesulitan dalam menguasai konsep kubus dan balok, menemukan rumus luas permukaan kubus balok, dan menggunakan rumus luas permukaan kubus dan balok. Kesulitan menggunakan rumus pada penyelesaian soal sebagai akibat dari menghafal rumus siap pakai, sehingga siswa sering lupa dengan rumus. Alternatif pemecahan kesulitan belajar siswa tersebut, yaitu: (a) Menggunakan aplikasi komputer (Power point, Ms Word dengan SmartArt Graphic) dan software seperti Cabri Geometry, The Geometer's Sketchpad (GSP), Geometry Expert, Logo, Geogebra, dan Wingeom; (b) Mengaktifkan dengan baik materi prasyarat tentang bangun datar yang menjelaskan sisi-sisi pada bangun ruang; (c) Menerapkan metode penemuan terbimbing menggunakan LKS terbimbing; dan (d) memperbanyak mengerjakan latihan soal baik yang bersifat kontekstual maupun soal-soal yang bersifat non-kontekstual.
\end{abstract}

Kata Kunci: Analisis; Kesulitan; Pemahaman; Kubus Balok; Alternatif Pemecahan

Abstract: The descriptive research aims to diagnose the difficulties of secondary school students in understanding Cube and Rectangular Prism and formulate the alternative solution. Geometry test and interview are used as the instrument. The subjects are 3 seventh grade students who respectively represent high, medium and low ability in mathematics. This research finds that the students have difficulties in understanding the properties of cube and rectangular prism, inventing the surface area, and using the formula to determine the surface area. The difficulty in using the formula to solve related problems is an effect

\footnotetext{
1 Sekolah Tinggi Agama Islam Negeri (STAIN) Curup, JI. DR. AK. Ghani No.01 Kabupaten Rejang Lebong Provinsi Bengkulu, Indonesia, mutianasir24@gmail.com
} 
of memorizing ready-made formula without understanding so the students are easy to forget it. The alternative ways to cope with the difficulties are: (a) Using computer application (PowerPoint, Ms Word with SmarArt Graphic) and other current softwares like Cabri Geometry, The Geometer's Sketchpad (GSP), Geometry Expert, Logo, Geogebra, and Wingeom; (b) Activating students' prior knowledge about plane which explains the side of the solid figures; (c) Implementing guided discovery learning with students' worksheet; and (d) giving variative exercises involving contextual or non-contextual problems.

Keywords: Analysis; Difficulties; Understanding; Cube Prism; Alternative Solution

\section{A. Pendahuluan}

Objek kajian matematika berupa fakta, konsep, operasi dan prinsip bersifat abstrak. Dalam pembelajaran, perlu ada kesesuaian objek yang dipelajari. Siswa tidak hanya mampu melakukan perhitungan, tetapi juga memahami konsep matematika agar pembelajaran matematika menjadi bermakna. Siswa tidak hanya sekedar menghafal rumus dan menggunakannya untuk mencari hasil. Keabstrakan matematika semakin bisa dipahami dengan memperkaya dan menghubungkan konsep-konsep yang beraneka ragam. Seperti halnya dalam mempelajari kubus dan balok, siswa tidak dapat menjelaskan keabstrakan kubus dan balok jika siswa hanya dijelaskan definisi-definisi tanpa menunjukkan bendanya secara langsung. Objek-objek yang dipelajari memang ada yang mudah dan sulit, namun Hudojo (1988) menegaskan bahwa siswa akan mudah mempelajari matematika, apabila siswa telah mengetahui konsep dengan baik.

Dalam pembelajaran di kelas, objek matematika tersebut dirasakan sulit untuk dipelajari siswa apalagi dalam pemahaman konsep. Hal ini disebabkan karena dalam proses belajar matematika, siswa sering dihadapkan dengan rumus sementara matematika membutuhkan keterkaitan antara objek-objeknya. Matematika juga membutuhkan penalaran yang logis dalam menyelesaikan beberapa bentuk soal cerita dan konsep. Artinya, bahwa dalam penyelesaian soal-soal matematika tidak hanya membutuhkan hasil, akan tetapi proses berpikir siswa dalam menyelesaikannya sehingga matematika bukan hanya tentang hasil tetapi juga proses yaitu penalaran logis. 
Siswa dapat menerima materi dan menyelesaikan soal-soal tapi tidak dapat menjadikannya bermakna. Bermakna di sini maksudnya adalah siswa dapat menguasai materi tidak hanya untuk menjawab soal akan tetapi dapat menyelesaikan masalah lainnya di luar konteks soal tersebut. Misalnya, jika diberikan soal yang berbeda bentuknya atau diberikan tingkat soal yang lebih sulit, siswa juga dapat menyelesaikannya, namun kenyataannya siswa seringkali masih merasa kesulitan dan akhirnya menyerah jika tidak dapat mengerjakannya. Hal ini disebabkan karena tidak memahami konsep yang dipelajari sehingga menjadi lupa dan kesulitan. Kesulitan ini akan mempengaruhi proses belajar siswa seperti membuat kesalahan dalam menyelesaikan masalah matematika dan hasil belajarnya (Sucipto \& Mauliddin, 2016).

Saat ini, hasil belajar matematika siswa masih belum memenuhi harapan, hal ini dapat dilihat dari hasil Ujian Nasional yang dianggap dapat mewakili hasil belajar siswa selama belajar di sekolah. Diketahui rata-rata Ujian Nasional Matematika siswa masih rendah yaitu 5,26 seperti yang ditunjukkan pada tabel berikut.

Tabel 1. Nilai Ujian Nasional

\begin{tabular}{|c|l|c|c|c|c|}
\hline No & \multicolumn{1}{|c|}{ Uraian } & $\begin{array}{c}\text { Bahasa } \\
\text { Indonesia }\end{array}$ & $\begin{array}{c}\text { Bahasa } \\
\text { Inggris }\end{array}$ & Matematika & IPA \\
\hline 1 & Nilai tertinggi & 9,20 & 8,40 & 8,25 & 9,25 \\
\hline 2 & Nilai terendah & 3,60 & 2,60 & 2,75 & 4,00 \\
\hline 3 & Rata-rata & 7,16 & 5,41 & 5,26 & 6,79 \\
\hline
\end{tabular}

Sumber: Data Ujian Nasional SMP 03 Karangpandan

Hampir setiap tahun, guru dan siswa mengeluhkan hasil belajar matematika tersebut sehingga anggapan sebagian besar siswa mengenai matematika sebagai mata pelajaran yang sulit masih tidak bisa terlepaskan. Di lain pihak, guru juga merasa kesulitan saat menyampaikan materi, siswa menerima materi yang diajarkan tetapi belum tentu mampu mengerjakan persoalan matematika. Apalagi materi ajar yang diberikan berhubungan dengan materi yang objeknya abstrak seperti geometri.

Menurut Stein (1980), objek geometri bersifat abstrak. Hal ini tampak jelas pada pendapatnya tentang titik, garis, bidang, dan ruang yang menjelaskan bahwa geometri merupakan salah satu cabang matematika yang bersifat abstrak yang membicarakan titik, garis, bidang, ruang dan keterkaitan satu sama lainnya. Mempelajari geometri dapat 
menumbuhkan dan mengembangkan kemampuan berfikir logis siswa, namun pada kenyataannya geometri menempati posisi yang memprihatinkan di antara cabang matematika lainnya yang dipelajari di SMP seperti aljabar dan aritmetika. Data dari guru yang mengajar matematika di SMP Negeri 3 Karangpandan berikut menunjukkan hasil belajar siswa untuk geometri, aljabar, dan aritmetika :

Tabel 2. Nilai Rata-rata Pencapaian Siswa Pada Akhir Pokok Bahasan

\begin{tabular}{|c|l|c|}
\hline No & \multicolumn{1}{|c|}{ Matematika SMP } & Nilai rata-rata \\
\hline 1. & Aljabar & 44 \\
\hline 2. & Aritmetika & 56 \\
\hline 3. & Geometri kelas VIII & 42 \\
\hline 4. & Geometri Kelas VII & 53 \\
\hline
\end{tabular}

Pada tabel 2 terlihat perbedaan nilai rata-rata pencapaian materi geometri siswa di kelas VII dan VIII. Nilai rata-rata yang diperoleh siswa pada materi pokok bangun datar lebih tinggi daripada materi bangun ruang yang dipelajari di kelas VIII. Perbedaan ini setidaknya memberikan informasi bahwa pembelajaran geometri di kelas VII lebih baik dibandingkan dengan pembelajaran geometri di kelas VIII. Hal ini menyebabkan penulis memilih menganalisis kesulitan siswa pada geometri ruang di kelas VIII. Selaras dengan hal tersebut, berdasarkan keterangan guru yang mengajar di kelas VIII tersebut juga menjelaskan bahwa siswa merasa lemah di geometri ruang disebabkan siswa mengalami kesulitan saat mempelajari konsep-konsep bangun ruang seperti kubus dan balok yang memiliki titik, bidang, ruang, dan hubungan di antaranya. Kesulitan tersebut, misalnya: 1) Siswa belum dapat menentukan unsur-unsur kubus dan balok seperti titik sudut, rusuk, dan lainnya; 2) Siswa masih menyamakan istilah sisi pada bangun datar dengan bidang sisi pada bangun ruang; 3) Siswa belum bisa membedakan bidang diagonal dan diagonal ruang; 4) Siswa belum dapat menjelaskan bidang diagonal itu bentuknya seperti bangun datar apa, ada yang menyebutkan jajar genjang padahal bentuknya persegi panjang. Jika kesulitan belajar ini tidak dianalisis lebih lanjut akan dapat menyebabkan pemahaman yang kurang sempurna terhadap konsep-konsep geometri selanjutnya yaitu geometri di kelas IX dan di jenjang yang lebih tinggi seperti Sekolah Menengah Atas (SMA) hingga Perguruan Tinggi. 
Sementara itu, hasil evaluasi Programme for International Student Assessment (PISA) prestasi belajar matematika di Indonesia untuk siswa usia 13 tahun masih rendah. Pada PISA tahun 2006, Indonesia berada pada peringkat 50 dari 57 negara dengan rerata skor 391 (OECD, 2007). Soal-soal matematika dalam studi PISA lebih banyak mengukur kemampuan menalar, memecahkan masalah dan berargumentasi daripada soal-soal yang mengukur kemampuan teknis baku yang berkaitan dengan ingatan dan perhitungan semata. Rendahnya kemampuan siswa dalam menyelesaikan permasalahan matematika akan mempengaruhi penyelesaian masalah geometri, dan pada umumnya siswa di sekolah menengah mengalami kesulitan dalam mempelajarinya (Sulistyaningsih, 2016).

Adapun Imswatama dan Muhassanah (2016) juga pernah melakukan penelitian yang hampir sama dengan penelitian ini yaitu menganalisis kesalahan mahasiswa dalam menyelesaikan soal geometri analitik bidang materi garis dan lingkaran. Hasil penelitian tersebut menunjukkan bahwa kesalahan mahasiswa dalam menyelesaikan soal geometri analitik materi garis dan lingkaran adalah kesalahan konsep, kesalahan hitung, dan kesalahan sistematik. Perbedaannya dengan penelitian ini adalah objek materi yang diteliti yaitu kubus dan balok sedangkan penelitian yang dilakukan oleh Imswatama dan Muhassanah membahas garis dan lingkaran.

Berdasarkan beberapa permasalahan di atas, maka dapat dirumuskan masalah dalam penelitian ini, yaitu: Kesulitan belajar apa saja yang dialami siswa dalam memahami konsep kubus balok dan apa saja alternatif pemecahannya? Penelitian ini bertujuan untuk mendiagnosis kesulitan belajar siswa SMP pada pokok bahasan kubus balok dan menemukan alternatif pemecahannya.

\section{B. Metode Penelitian}

Jenis penelitian ini adalah penelitian deskriptif dengan pendekatan kualitatif. Adapun subjek penelitiannya adalah siswa kelas VIII SMP Negeri 3 Karang Pandan. Subjek dalam penelitian ini adalah tiga orang siswa yang masing-masing memiliki kemampuan tinggi, sedang, dan rendah. Alasan pemilihan 3 subjek tersebut adalah untuk merepresentasikan masingmasing tingkatan kemampuan siswa dan sebagai pembanding antara 
siswa satu dengan yang lainnya. Informasi mengenai tingkat kemampuan siswa ini, penulis dapatkan melalui wawancara dengan guru matematika yang mengajar di kelas VIII. Guru matematika tersebut lebih mengetahui tingkat kemampuan siswanya sehari-hari dalam proses pembelajaran yang didukung dengan nilai ulangan harian matematika pada pokok bahasan kubus dan balok serta nilai ulangan semester terakhir yang terangkum dalam Tabel 3 berikut

Tabel 3. Nilai Ulangan Harian dan Semester Matematika Siswa Kelas VIII

\begin{tabular}{|l|c|c|c|}
\hline No & Subjek Penelitian & $\begin{array}{c}\text { Nilai Ul. Harian kubus } \\
\text { dan balok }\end{array}$ & $\begin{array}{c}\text { Nilai Ulangan } \\
\text { Semester }\end{array}$ \\
\hline 1. & C & 80 & 75 \\
\hline 2. & B & 65 & 64 \\
\hline 3. & A & 52 & 50 \\
\hline
\end{tabular}

Keterangan:

Subjek $\mathrm{C}=$ kemampuan tinggi

Subjek $A=$ kemampuan rendah

Subjek $B=$ kemampuan sedang

Instrumen yang digunakan dalam penelitian ini adalah tes geometri dan wawancara. Tes geometri merupakan tes tertulis yang dirancang untuk mengidentifikasi kesulitan yang dialami siswa dalam menyelesaikan persoalan geometri khususnya kubus dan balok. Estenberg (2002) mendefinisikan wawancara sebagai pertemuan dua orang untuk bertukar informasi dan ide melalui tanya jawab sehingga dapat dikonstruksikan makna dalam suatu topik tertentu. Wawancara dirancang untuk mempermudah penulis dalam menggali informasi mengenai kesulitan belajar siswa pada tes geometri yang diberikan dalam memahami konsep kubus dan balok. Adapun jenis wawancara yang digunakan dalam penelitian ini adalah wawancara tak terstruktur (unstructured interview). Menurut Sugiyono (2016) wawancara tidak terstruktur merupakan wawancara yang bebas di mana peneliti tidak menggunakan pedoman wawancara yang telah tersusun secara sistematis dan lengkap untuk pengumpulan datanya. Analisis data dilakukan dengan cara membandingkan data hasil tes geometri dengan data hasil wawancara. 


\section{Temuan dan Pembahasan}

Untuk mengetahui letak kesulitan siswa dalam pemahaman konsep dapat ditentukan dari kesalahan-kesalahan siswa dalam menuliskan setiap langkah kerjanya dalam menyelesaikan masalah matematika.

Berikut contoh hasil kerja siswa yang melakukan kesalahan:

Soal No. 1

Gambarkanlah sebuah kubus $A B C D$.EFGH dan sebutkan unsurunsur yang dimilikinya! Berdasarkan unsur-unsur yang dimiliki kubus tersebut, coba jelaskan pengertian dari kubus !

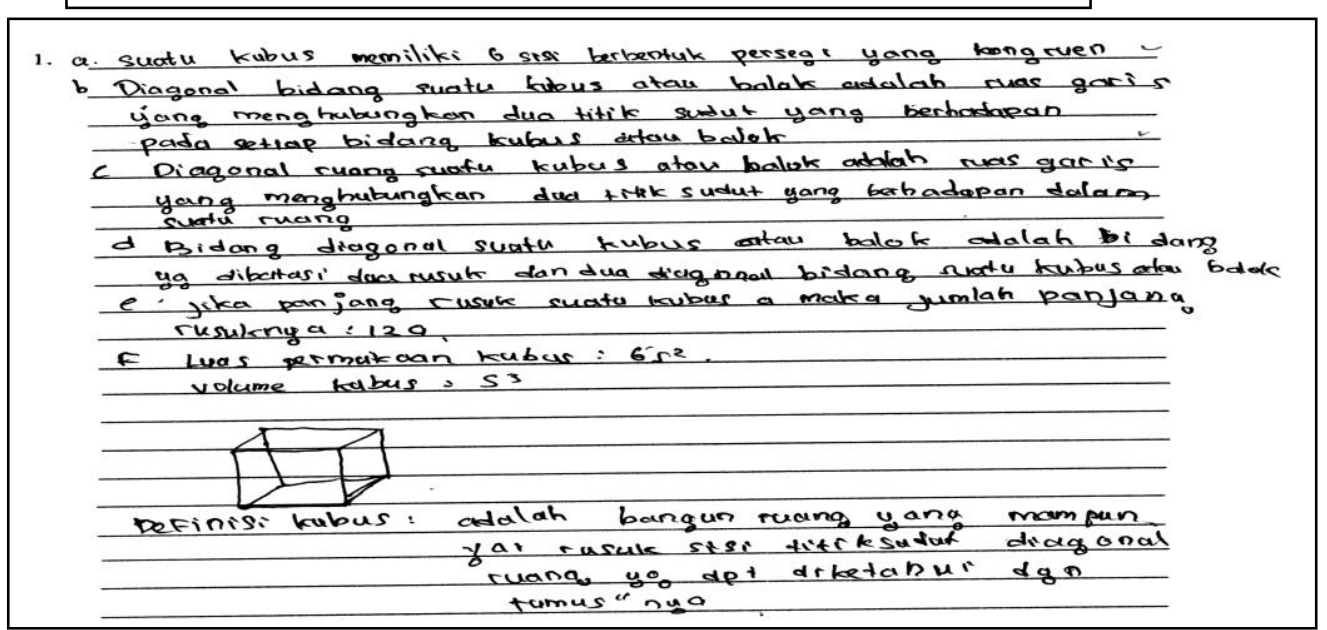

Gambar 1. Jawaban Subjek A untuk Soal No. 1

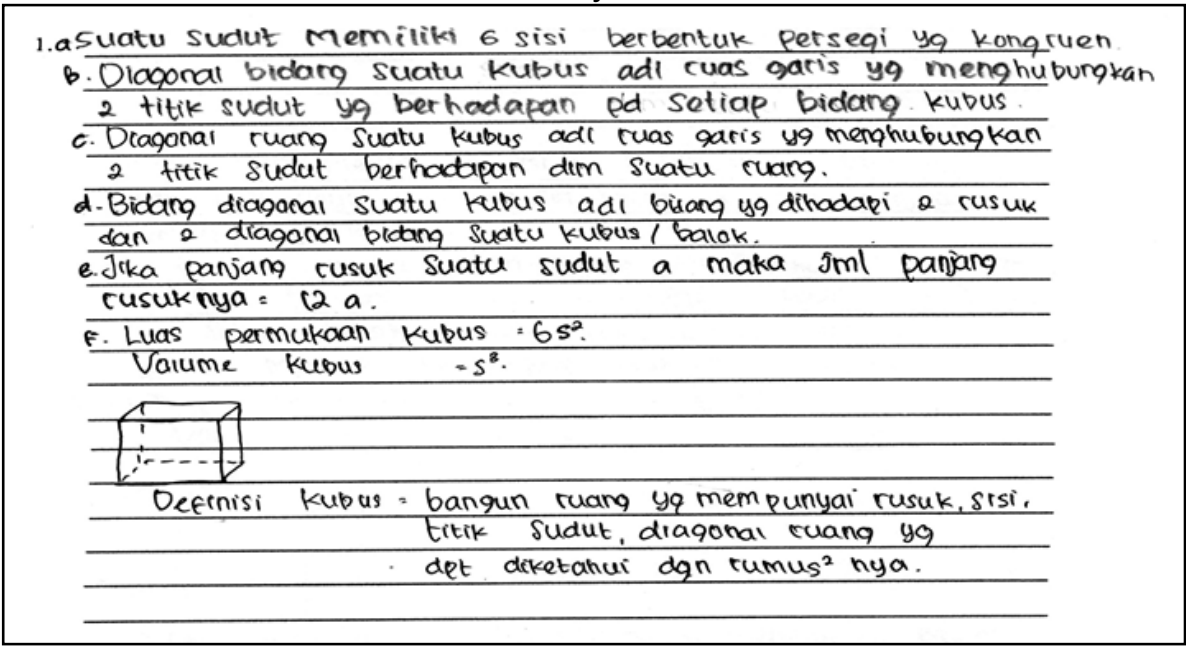

Gambar 2. Jawaban Subjek B untuk Soal No. 1 


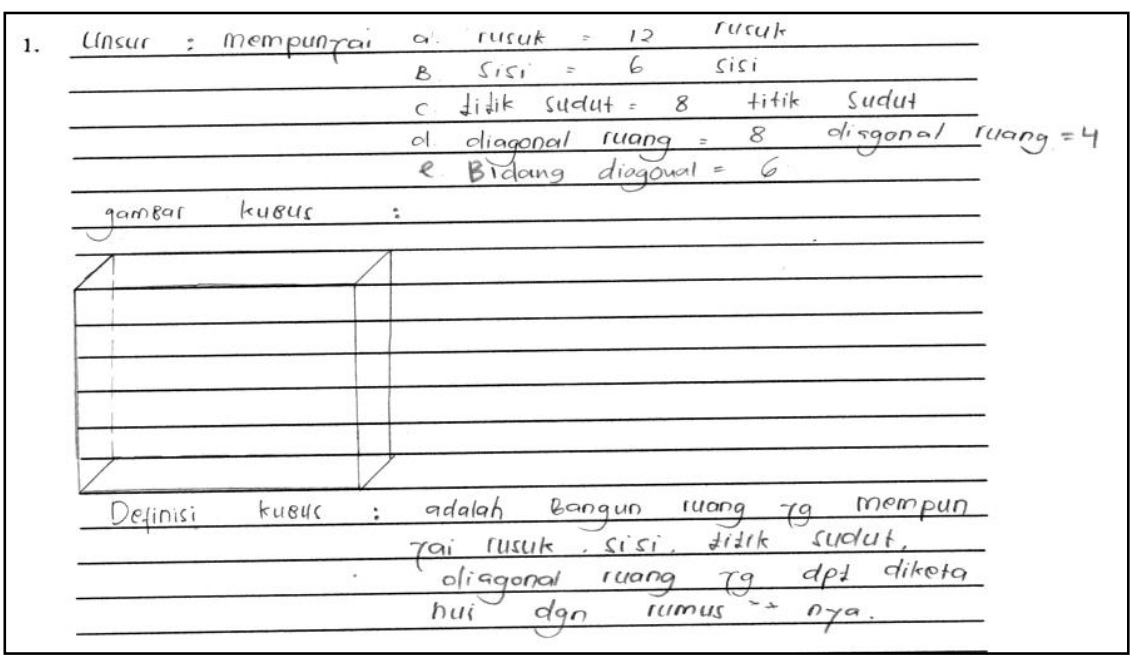

Gambar 3. Jawaban Subjek C untuk Soal No. 1

Berdasarkan hasil kerja siswa di atas (Gambar 1-3), subjek A belum mampu menuliskan semua unsur-unsur kubus, hanya beberapa saja yang bisa disebutkan, belum memahami soal, dan dalam mendefinisikan kubus masih terkesan bersifat teks atau hafalan atau bukan karena benar-benar memahami konsep. Subjek B juga melakukan kesalahan yang sama dengan subjek $A$. Subjek $C$ sudah dapat menuliskan unsur-unsur kubus dan jumlahnya. Namun, masih terdapat kesalahan pada diagonal bidang, subjek $C$ menuliskan jumlah diagonal ruang ada 8 dan 4 sehingga tidak jelas yang mana dimaksud dengan diagonal ruang. Selain itu, semua subjek juga belum bisa menunjukkan unsur-unsur pada gambar dan memberikan pengertian kubus dengan jelas.

Soal No. 2 Perhatikan gambar kubus $A B C D$.EFGH berikut

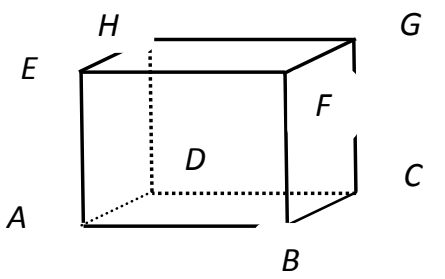

Jika rusuk-rusuk sejajar pada gambar kubus di atas direbahkan, maka akan terbentuk jaring-jaring kubus. Gambarkanlah salah satu bentuk jaring-jaring kubus tersebut! 


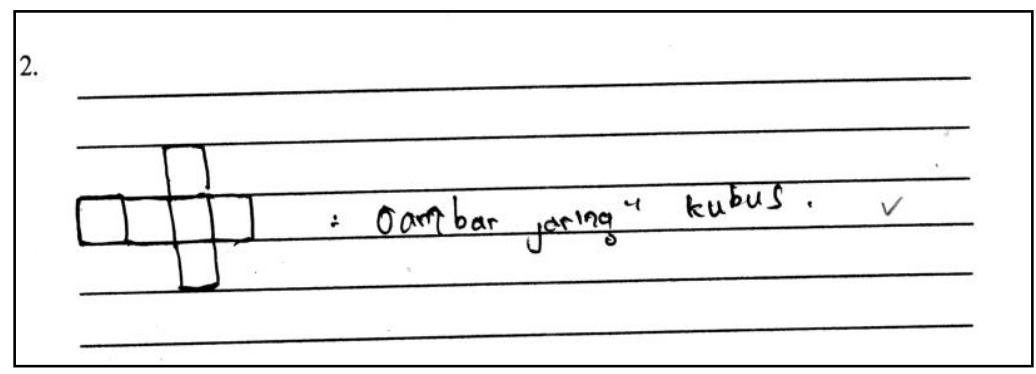

Gambar 4. Jawaban Subjek A untuk soal No. 2

2.

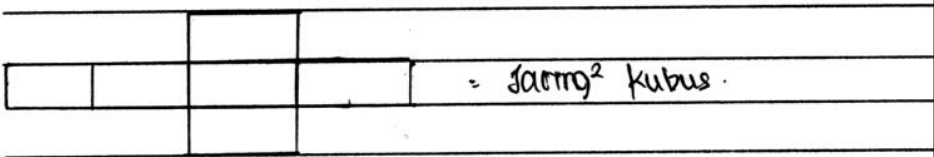

Gambar 5. Jawaban Subjek B untuk soal No. 2

Pada subjek $A$, siswa dapat membuat salah satu jaring-jaring kubus (Gambar 4) tetapi belum dapat menuliskan bidang sisi alas, atas, samping kanan dan kiri, serta depan dan belakang pada jaring-jaring sehingga jaring-jaring kubus yang dibuat belum jelas. Pada Subjek B, jaring-jaring kubus yang dibuat (Gambar 5) bukan merupakan jaring-jaring kubus karena setiap bidang sisi yang digambar bukan bidang sisi yang kongruen. Dengan demikian, subjek $A$ dan $B$ belum dapat menggambarkan jaringjaring kubus dengan baik meskipun bentuk jaring-jaring yang digambarkan sudah benar karena belum menunjukkan bidang alas, tutup, samping kanan, kiri, depan, dan belakangnya. Subjek $\mathrm{C}$ menjawab dengan baik dan benar (tidak ditampilkan).

Soal No. 3

Dari jaring-jaring kubus yang telah dibuat pada soal nomor 2, temukanlah rumus luas permukaan kubus dengan panjang rusuk $s$ dan hitunglah luas permukaan kubus jika diketahui $s=10 \mathrm{~cm}$ ! 


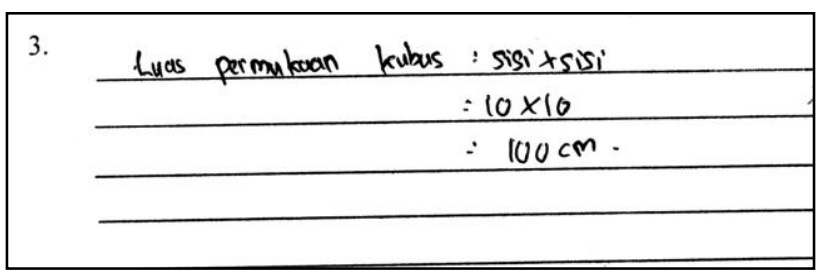

Gambar 6. Jawaban Subjek A untuk soal No. 3

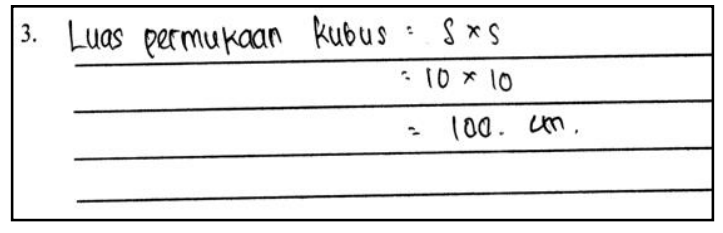

Gambar 7. Jawaban Subjek B untuk soal No. 3

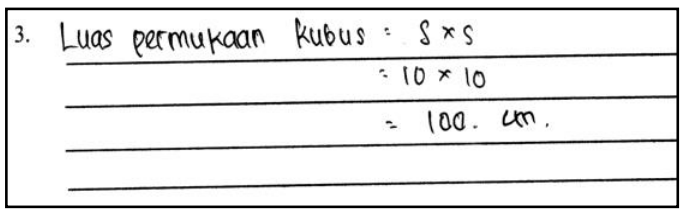

Gambar 8. Jawaban Subjek C untuk soal No. 3

Subjek A, B, dan C tidak dapat menemukan rumus luas permukaan kubus dan menggunakannya dengan tepat. Tidak ditemukan langkahlangkah menemukan rumus. Padahal dalam soal sudah diberi petunjuk, siswa dapat menemukan rumus luas permukaan dari jaring-jaring kubus yang digambarkan. Siswa menuliskan rumus luas permukaan kubus $=$ sisi $x$ sisi. Padahal $L=$ sisi $x$ sisi itu adalah rumus luas persegi, sehingga siswa belum dapat membedakan persegi dan kubus.

Soal No. 4

Gambarkanlah sebuah balok $A B C D$.EFGH dan sebutkan unsur-unsur yang dimilikinya ! Berdasarkan unsur-unsur yang dimiliki balok tersebut, coba jelaskan pengertian dari balok dan bedanya dengan kubus! 


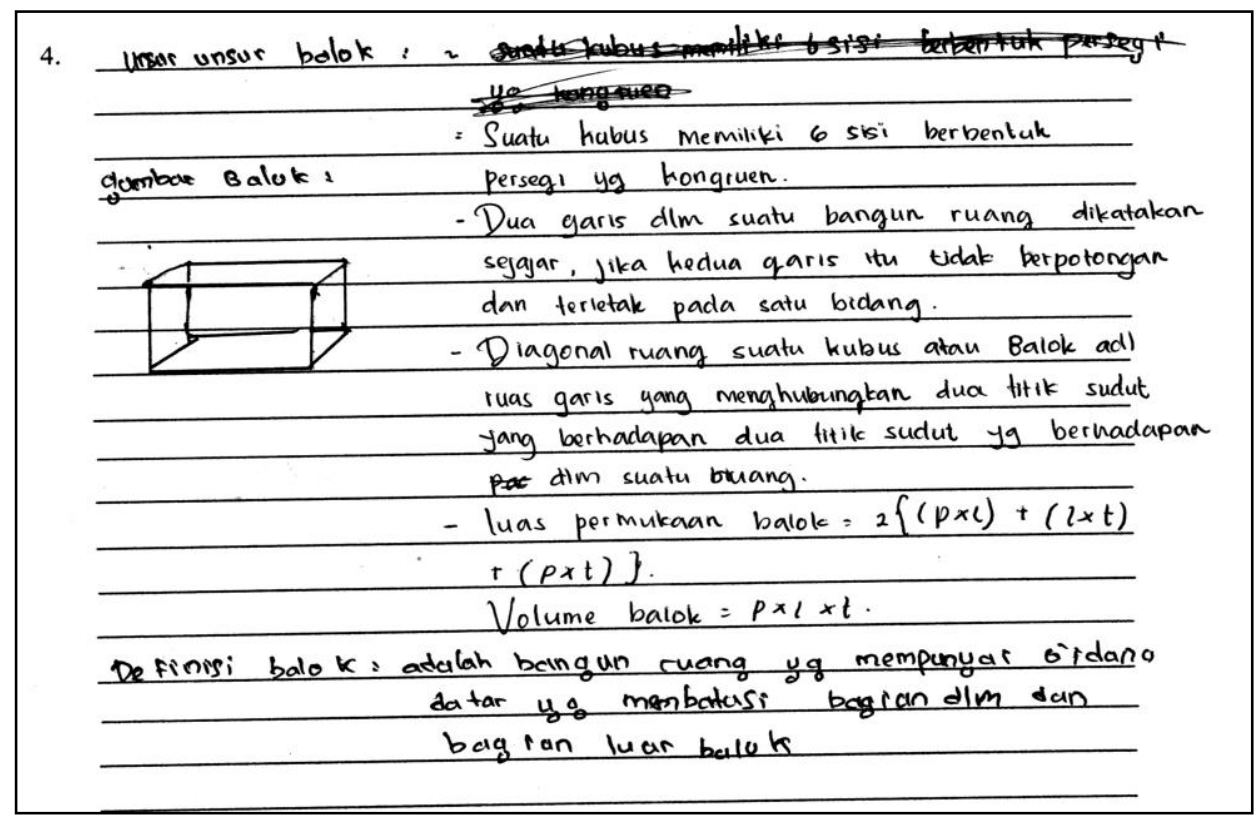

Gambar 9. Jawaban Subjek A untuk soal No. 4

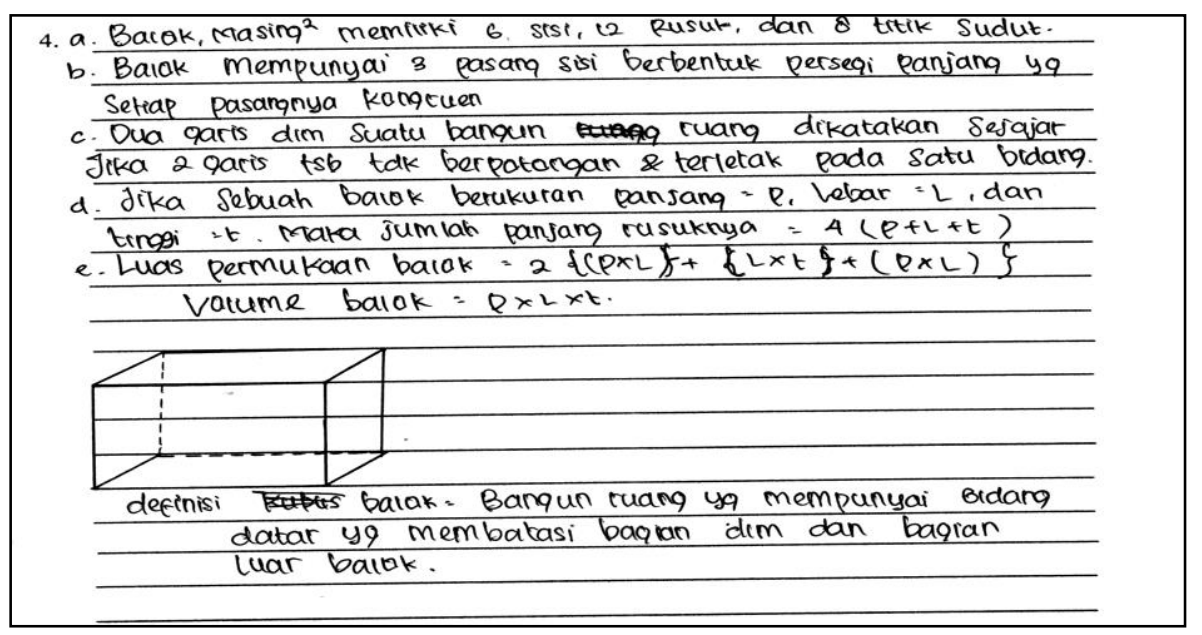

Gambar 10. Jawaban Subjek B untuk soal No. 4 


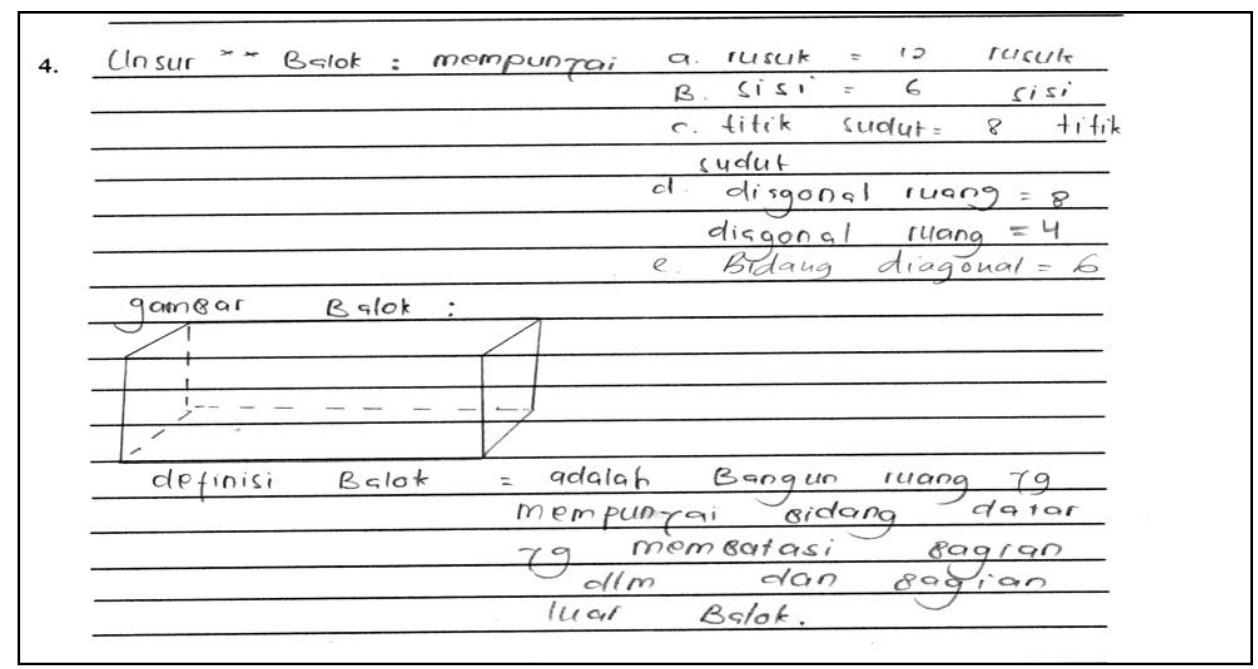

Gambar 11. Jawaban Subjek C untuk soal No. 4

Hasil kerja subjek $A$ untuk nomor 4 menunjukkan bahwa subjek $A$ belum dapat menuliskan unsur-unsur balok, memberikan pengertian balok dengan jelas, dan membedakannya dengan kubusSubjek B dapat menuliskan unsur-unsur balok dan jumlahnya. Subjek A dan B sudah mengetahui bahwa bidang sisi pada balok berjumlah 6 buah, rusuk 12 buah, dan 8 titik sudut. Di sini, subjek A dan B dapat menyebutkan bahwa balok memiliki 3 pasang bidang sisi berbentuk persegi yang kongruen, namun dalam memberikan pengertian balok masih belum tepat. Subjek $C$ dapat menyebutkan unsur-unsur balok dan jumlah setiap unsurnya. Namun, masih terdapat kesalahan pada diagonal ruang, da 2 diagonal ruang yang disebutkan. Pengertian balok yang dituliskan juga masih belum tepat.

Soal No. 5

Perhatikan gambar balok berikut

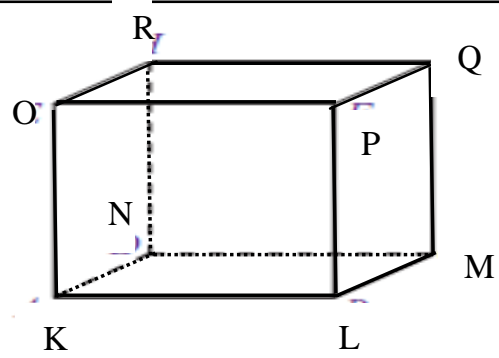


Jika balok tersebut memiliki ukuran panjang $p \mathrm{~cm}$, lebar $/ \mathrm{cm}$, dan tinggi $t \mathrm{~cm}$. Temukanlah luas permukaan balok tersebut dan jika diketahui $p=18 \mathrm{~cm}, I=12 \mathrm{~cm}, t=8 \mathrm{~cm}$ maka hitunglah luas permukaan balok tersebut !

(Dalam menemukan rumus luas permukaan balok, gunakan jaringjaring balok).

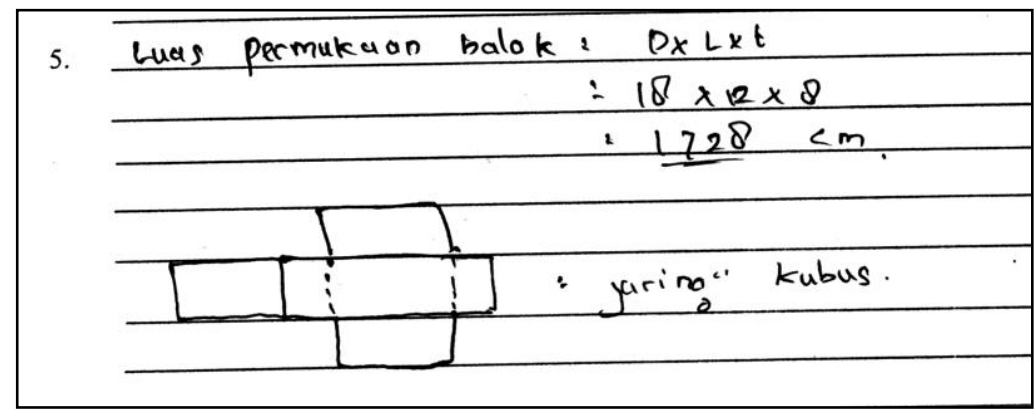

Gambar 12. Jawaban Subjek A untuk soal No. 5

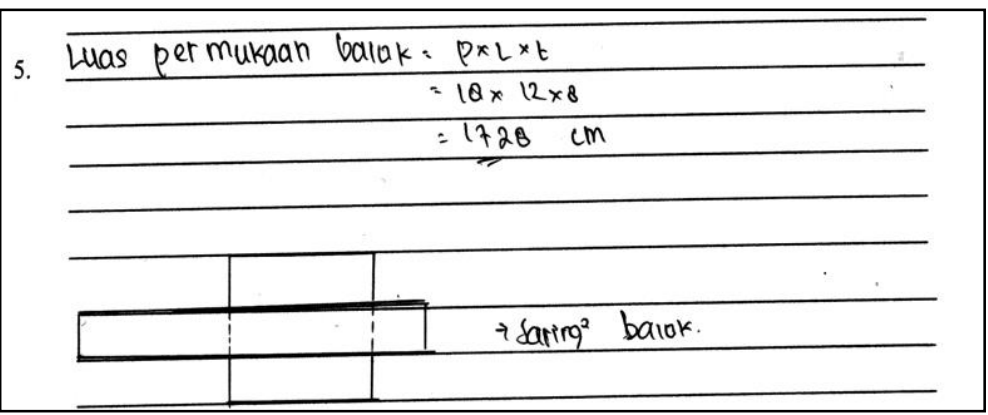

Gambar 13. Jawaban Subjek B untuk soal No. 5

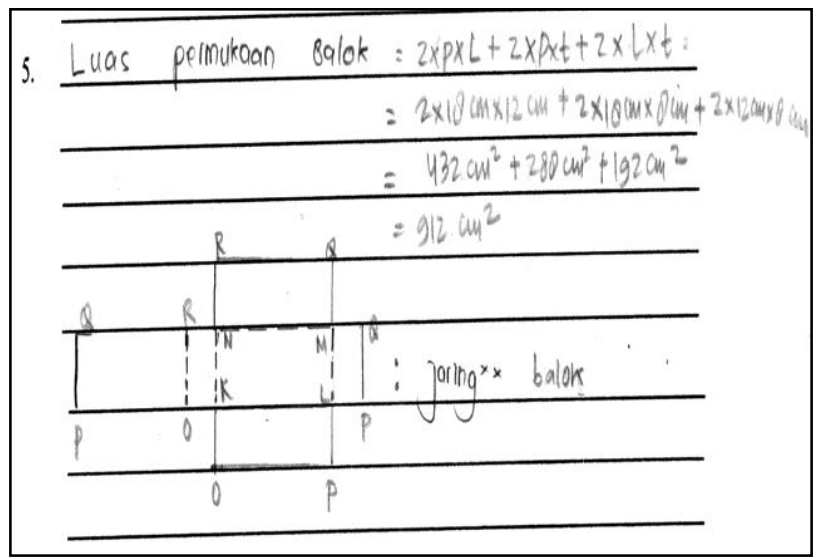

Gambar 14. Jawaban Subjek C untuk soal No. 5 
Subjek A dan B tidak dapat menemukan rumus luas permukaan balok karena tidak ditemukan langkah-langkah dalam menemukan rumus. Terdapat kesalahan dalam penggunaan rumus yaitu rumus volume balok untuk luas permukaan balok. Ini adalah kesalahan besar dari siswa, tidak bisa membedakan luas permukaan dan volume. Sedangkan subjek $C$ sudah dapat menggunakan rumus luas permukaan balok dari jaring-jaring balok.

Kesulitan-kesulitan yang ditemukan pada siswa berdasarkan kesalahan-kesalahan yang terjadi saat mengerjakan soal kubus dan balok , yaitu:

1. Kesulitan menguasai konsep kubus dan balok

Kesulitan ini meliputi kesulitan menyebutkan dan menunjukkan unsur-unsur kubus dan balok yang terdiri dari titik sudut, rusuk, bidang sisi, diagonal bidang, diagonal ruang, dan bidang diagonal pada gambar. Hal ini terlihat dari jawaban siswa pada soal no 1 dan 4 untuk subyek A, B, dan C. Siswa sebenarnya telah dapat menyebutkan unsur-unsurnya beserta pengertiannya, meskipun belum ditunjukkan dengan gambar. Namun, untuk melihat pemahaman yang lebih dalam dan menemukan kesulitannya, dilakukan wawancara dan ternyata dari hasil wawancara, siswa tidak dapat menunjukkan unsur-unsur kubus dan balok tersebut secara jelas. Ini berarti bahwa siswa belum dapat memahami unsurunsurnya. Hal ini dapat dicermati bahwa kesulitan ini terjadi karena pengertian yang diterima tidak terkait dengan pemahaman fakta yang dimiliki. Pengertian yang dibangun dengan cara menghafal dari buku atau sewaktu pelajaran.

Selain itu, terdapat juga kesulitan membedakan konsep sisi pada bangun datar dan bidang sisi pada bangun ruang. Siswa masih keliru dalam menggunakannya. Siswa menggunakan istilah "sisi" pada kubus bukan "bidang sisi". Hal ini disebabkan karena siswa masih menyamakan konsep sisi pada bangun datar dengan bangun ruang. Kemudian, kesulitan selanjutnya adalah kesulitan mendefinisikan kubus dan balok.

Menurut Sumardyono (2004), konsep adalah idea abstrak yang dapat digunakan untuk menggolongkan atau mengkategorikan sekumpulan objek, apakah objek tertentu merupakan contoh konsep atau bukan. Konsep dapat dipelajari lewat definisi atau observasi langsung. Siswa telah 
dianggap memahami konsep bila ia dapat memisahkan contoh konsep dari yang bukan contoh konsep.

\section{Kesulitan menemukan rumus}

Adapun kesulitan menemukan rumus meliputi kesulitan menemukan rumus luas permukaan kubus dan balok. Kesulitan ini dapat ditemukan saat melihat kesalahan siswa dalam mengerjakan soal nomor 3 yaitu menemukan rumus luas permukaan kubus. Tidak ada satu langkah pengerjaan pun yang bisa dilakukan siswa. Hal ini disebabkan karena siswa tidak mengerti dan tidak terbiasa dengan masalah seperti itu. Siswa terbiasa menggunakan rumus "siap pakai" untuk penyelesaian soal. Begitu juga dalam menemukan rumus luas permukaan balok, subjek tidak dapat menemukan rumus luas permukaan balok berdasarkan jaring-jaring balok yang telah diketahui. Padahal sebuah rumus luas permukaan kubus atau balok dapat dipahami melalui sebuah jaring-jaring tersebut.

\section{Kesulitan menggunakan rumus}

Adapun kesulitan penggunaan rumus meliputi kesulitan penggunaan rumus luas permukaan kubus dan balok. Saat menghitung luas permukaan kubus dan balok, Semua subyek penelitian mengalami kesalahan. Siswa menggunakan kembali konsep di kelas VII yaitu $L=$ sisi $x$ sisi, padahal itu rumus luas persegi dan bukan kubus. Ketika diwawancarai, siswa menjawab masih terbawa dengan konsep bangun datar di kelas VII dan ada juga yang menjawab lupa. Begitu juga dengan balok, dalam penyelesaian soal yang melibatkan rumus dan perhitungan, siswa belum dapat membedakan rumus volume balok dan luas permukaan balok.

Melihat kesulitan yang dialami siswa dalam memahami kubus dan balok, maka ada solusi yang dapat ditawarkan untuk mengatasi kesulitan tersebut antara lain:

1. Mengatasi kesulitan siswa dalam penguasaan konsep kubus dan balok dapat dilakukan dengan menggunakan alat peraga atau media sederhana. Alat peraga yang digunakan misalnya kerangka kubus dan balok, sementara media sederhana misalnya benda-benda nyata yang dapat ditemukan dalam kehidupan sehari-hari yang berbentuk kubus dan balok seperti kotak pepsodent, kotak teh, atau kotak lainnya yang berbentuk kubus atau balok. Dengan media sederhana ini guru menyebutkan dan menunjukkan unsur-unsur kubus dan balok pada kotak-kotak tersebut dan selanjutnya siswa mengamati secara 
langsung unsur-unsur yang dimaksud. Dengan demikian upaya tersebut dapat menghubungkan konsep yang dimiliki siswa melalui fakta yang ada. Namun, penggunaan alat peraga ini tidak bisa selamanya membuat siswa memiliki ingatan yang lama dalam mempelajari dan memahami konsep kubus dan balok. Oleh sebab itu, diberikan alternatif pemecahan lainnya yang dapat memberikan ingatan lama kepada siswa untuk memami konsep kubus dan balok yaitu dengan mengupayakan pembelajaran menggunakan media berbasis komputer seperti penggunaan aplikasi power point yang dapat ditemukan di semua Microsoft Office komputer, sehingga tidak sulit menemukannya. Power point dapat digunakan karena memiliki shapes dan animation yang dapat digunakan untuk memberikan bentuk geometri secara visual. Namun, terkadang menggunakan power point juga masih dirasa kesulitan oleh guru, karena perlu keterampilan guru dalam membuatnya.

Selanjutnya, dapat menggunakan Microsoft Word 2007 yang dilengkapi dengan SmartArt Graphic. Menurut Marsigit (2010), keterampilan membuat bangun-bangun geometri yang lebih kompleks, seperti bangun-bangun geometri dimensi 3 dapat menggunakan fasilitas Microsoft Word 2007 yang dikembangkan dari keterampilan membuat bangun datar. Dengan menggunakan Microsoft Word 2007 siswa dapat melakukan investigasi atau penyelidikan konsep-konsep geometri dan melakukan kegiatan problem solving atau pemecahan masalah matematika. Dengan demikian, Microsoft Word 2007 yang dilengkapi dengan SmartArt Graphic dapat dicoba untuk digunakan oleh guru dalam pembelajaran geometri.

Selain itu, dapat juga dilakukan dengan penggunaan software pembelajaran geometri yang telah dikembangkan saat seperti Cabri Geometry (Cabri I dan Cabri II), The Geometer's Sketchpad (GSP), Geometry Expert, Logo, Geogebra, dan Wingeom. Adapun Himmawati (2010) mengemukakan dalam penelitiannya bahwa program Cabri dapat digunakan untuk mempermudah memahami konstruksi geometri dan teorema-teorema dalam geometri. Selain itu, dalam pembelajaran menggunakan The Geometer's Sketchpad (GSP), ChoiKoh (2000) dan Olkun, Sinoplu, dan Deryakulu (2005) mengemukakan bahwa GSP dapat membantu menciptakan suatu situasi yang potensial 
di dalam kelas untuk membangun atau mengembangkan kemampuan berfikir dalam belajar geometri yang berujung pada pemahaman siswa terhadap konsep-konsep geometri yang abstrak.

Mengatasi kesulitan dalam membedakan konsep sisi pada bangun datar dan bidang sisi pada bangun ruang, guru dapat mengingatkan kembali siswa pada materi persegi dan persegi panjang terlebih dahulu yaitu dengan menjelaskan bahwa persegi dan persegi panjang itu merupakan bangun datar yang hanya memiliki sisi-sisi panjang dan lebar. Sedangkan kubus dan balok merupakan bangun ruang yang terbentuk dari bangun-bangun datar tersebut. Dengan menghubungkan pemahaman konsep geometri yang didapatkan pada materi sebelumnya dengan kubus dan balok yang dipelajari sekarang, diharapkan siswa dapat memahami konsep kubus dan balok nantinya.

Mengatasi kesulitan siswa dalam mendefinisikan kubus dan balok dapat dilakukan dengan membuat siswa memahami unsur-unsurnya terlebih dahulu, kemudian membimbing siswa untuk dapat mengungkapkan pengertian kubus dan balok secara tertulis dengan kata-katanya sendiri berdasarkan konsep yang dimilikinya.

2. Mengatasi kesulitan siswa dalam menemukan rumus luas permukaan kubus dan balok dapat dilakukan dengan menerapkan metode penemuan terbimbing. Menurut Sagala (2010), dalam penemuan terbimbing, siswa lebih banyak melakukan kegiatan sendiri atau dalam bentuk kelompok memecahkan permasalahan dengan bimbingan guru. Misalnya, untuk menemukan rumus luas permukaan kubus dan balok. Siswa dapat melakukannya sendiri atau secara berkelompok melalui percobaan eksperimen kecil menggunakan kotak-kotak yang berbentuk kubus dan balok. Kemudian siswa menggunting unsur-unsur tegaknya yaitu "rusuk" pada model kubus dan balok sehingga terbentuk jaring-jaring kubus dan balok terlebih dahulu. Setelah itu, siswa diminta untuk menemukan sendiri bagaimana dapat menemukan rumus luas permukaan kubus dan balok dari kotak yang telah digunting tersebut. Hal ini tentunya juga tidak lepas dari bimbingan guru dan didukung dengan penggunaan LKS terbimbing untuk membantu pola pikir siswa menemukan rumus. Dengan adanya upaya ini diharapkan siswa dapat meningkatkan pemahaman konsepnya. Sagala (2010) juga mengatakan bahwa dengan 
menggunakan metode penemuan terbimbing ini dapat mengembangkan kemampuan kognitif dan motorik siswa dengan membiasakan anak membuktikan atau menemukan sesuatu materi yang dipelajarinya.

3. Kesulitan siswa pada penggunaan rumus dapat diupayakan dengan memperbanyak mengerjakan latihan soal yang bervariasi baik yang bersifat kontekstual maupun non kontekstual. Hal ini bertujuan untuk memperkaya konsep siswa dan terbiasa dengan penyelesaian soal yang melibatkan penggunaan rumus luas permukaan kubus dan balok. Selain itu, juga perlu diberikan soal yang menggunakan rumus volume kubus dan balok, untuk meningkatkan pemahaman konsep siswa sehingga dapat membedakan rumus luas permukaan dan volume.

Kesulitan-kesulitan yang ditemukan dalam penelitian ini menunjukkan kesalahan yang sama pada penelitian Imswatama dan Muhassanah (2016). Pada penelitian tersebut menunjukkan bahwa terdapat empat kesalahan dalam mengerjakan soal geometri analitik antara lain kesalahan konsep, kesalahan strategi, kesalahan hitung, dan kesalahan sistematik. Serupa dengan penelitian ini, kesalahan yang ditemukan sebagai bentuk kesulitan belajar matematika siswa dalam memahami kubus dan balok adalah kesulitan memahami konsep dan kesulitan menggunakan rumus (kesalahan strategi) dan alternatif yang digunakan juga sama yaitu dengan memperbanyak latihan soal.

\section{Simpulan}

Berdasarkan analisis tes dan wawancara mengenai kesulitan belajar siswa pada materi kubus dan balok dapat disimpulkan kesulitan siswa meliputi: (a) Kesulitan menguasai konsep kubus dan balok yang terdiri dari kesulitan menyebutkan dan menunjukkan unsur-unsur kubus dan balok pada gambar, kesulitan membedakan konsep sisi pada bangun datar dan bidang sisi pada bangun ruang, dan kesulitan memberikan pengertian kubus dan balok. (b) Kesulitan menemukan rumus luas permukaan kubus dan balok. (c) Kesulitan menggunakan rumus luas permukaan kubus dan balok.

Alternatif pemecahan dari kesulitan belajar siswa tersebut, yaitu: (a) Untuk mengatasi kurangnya penguasaan konsep kubus dan balok 
dapat menggunakan alat peraga sederhana dan aplikasi komputer dan software seperti Cabri Geometry (Cabri I dan Cabri II), The Geometer's Sketchpad (GSP), Geometry Expert, Logo, Geogebra, dan Wingeom. Dengan menggunakan alternatif ini diharapkan siswa dapat lebih mudah memahami konsep bangun ruang karena diberikan penyajian secara visualisasi dimana unsur-unsur kubus dan balok dijelaskan secara konkret melalui gerakan gambar sehingga siswa tidak berimajinasi lagi dengan bentuk-bentuk unsur kubus dan balok tersebut. Guru juga dapat mengingatkan kembali siswa pada materi persegi dan persegi panjang terlebih dahulu, kemudian menghubungkan pemahaman konsep geometri yang didapatkan pada materi prasyarat dengan kubus dan balok yang dipelajari sekarang untuk mengatasi kesulitan dalam membedakan konsep sisi pada bangun datar dan bidang sisi pada bangun ruang. Untuk mengatasi kesulitan siswa dalam mendefinisikan kubus dan balok dapat dilakukan dengan membuat siswa memahami unsur-unsurnya terlebih dahulu, kemudian membimbing siswa untuk dapat mengungkapkan pengertian kubus dan balok secara tertulis dengan kata-katanya sendiri berdasarkan konsep yang dimilikinya. (b) Kesulitan siswa dalam menemukan rumus dapat diupayakan dengan menerapkan metode penemuan terbimbing yaitu menggunakan LKS terbimbing. (c) Kesulitan siswa pada penggunaan rumus dapat diupayakan dengan memperbanyak mengerjakan latihan soal yang bervariasi baik bersifat kontekstual maupun non kontekstual.

\section{Daftar Pustaka}

Choi-koh, S. (2000). The activities based on Van Hiele model using computer as a tool. Journal of the Korea Society of Mathematics Education Series D: Research in Mathematics Education, 4 (2), 63-67. Diakses di http://mathnet.kaist.ac.kr/mathnet/kms tex/115195.pdf

Estenberg, K. G. (2002). Qualitative methods in social research. Mc Graw Hill: New York.

Hudojo, H. (1988). Teori dasar belajar mengajar matematika. Jakarta: Depdikbud.

Imswatama, A., \& Muhassanah, N. (2016). Analisis kesalahan mahasiswa dalam menyelesaikan soal geometri analitik bidang materi garis dan lingkaran. Suska Journal of Mathematics Education, 2(1), 1-12. 
Lestari, H.P. (2010). Pemanfaatan media pembelajaran berbasis ICT dalam pembelajaran geometri.

Diakses

di

http://staffnew.uny.ac.id/upload/132280881/penelitian/PEMANFAA TAN+MEDIA+PEMBELAJARAN+BERBASIS+ICT+DALAM+PEMBELAJARA N+GEOMETRI_0.pdf

Marsigit. (2010). Memanfaatkan Microsoft Word 2007 sebagai media pembelajaran geometri di SMP. Diakses di http://staffnew.uny.ac.id/upload/131268114/penelitian/Memanfaat kan+Microsoft+Word+untuk+Pembelajaran+Matematika+di+SMP_M arsigit.Seminar+Media+Matematika.pdf

Nurhasanah, F. (2010). Abstraksi siswa SMP dalam belajar geometri melalui penerapan model Van Hiele dan Geometers Sketchpad. Diakses di http://repository.upi.edu/9784/

OECD. (2007). Executive summary PISA 2006. Diakses di http://www.oecd.org/pisa/pisaproducts/39725224.pdf

Olkun, S., Sinoplu, N.B., \& Deryakulu, D. (2005). Geometric explorations with dynamic geometry applications based on Van Hiele levels. International Journal for Mathematics teaching and Learning, 1-12. Diakses di http://www.cimt.org.uk/journal/olkun.pdf

Sagala, S. (2010). Konsep dan makna pembelajaran. Bandung: Alfabeta.

Stein, E. I. (1980). Fundamentals of mathematics (Seventh Edition). Boston: Allyn and Bacon, Inc.

Sucipto, L., \& Mauliddin, M. (2016). Analisis kesulitan belajar mahasiswa dalam memahami konsep bilangan real. Beta Jurnal Tadris Matematika, 9(2), 197-211. doi:10.20414/betajtm.v9i2.37

Sugiyono. (2016). Memahami penelitian kualitatif. Bandung: Alfabeta.

Sulistyaningsih, E. (2016). Analisis kemampuan pemecahan masalah matematika geometri PISA pada siswa kelas VIII semester genap SMP Negeri 1 Mojosongo Tahun 2015/2016. (Online). Diakses di http://eprints.ums.ac.id/44952/

Sumardyono. (2004). Karakteristik matematika dan implikasinya terhadap pembelajaran matematika. Yogyakarta: Departemen Pendidikan Nasional Direktorat Jenderal Pendidikan Dasar dan Menengah Pusat Pengembangan Penataran Guru Matematika. Diakses di http://asimtot.files.wordpress.com. 